\title{
Heavy Metals in Waters and Sediments of Rivers Affected by Brown Coal Mine Waters
}

\author{
Ryszard Staniszewski* \\ Department of Ecology and Environmental Protection, Faculty of Reclamation and Environmental Engineering, \\ Poznań University of Life Sciences, Piątkowska 94 C, 60-649 Poznań, Poland \\ Received: 11 February 2014 \\ Accepted: 9 May 2014
}

\begin{abstract}
As many as four rivers affected by brown coal mine waters were surveyed: Noteć (Lubstów open-pit mine), Pichna (Tomisławice), Widawka (Bełchatów), and Grójecki Channel (Drzewce). Identical procedures of sampling and laboratory analyses were applied in all of them. Heavy metal concentrations, $\mathrm{pH}$ reaction, and conductivity in river sediments were analyzed in warm periods of 2012 and 2013 to assess the impact of mine waters on riverbed material. Data on heavy metal concentrations, $\mathrm{pH}$, and conductivity of water were recorded in warm periods in 2011-13. For the Lubstów open-pit mine, closed in the year 2009, data from water samples collected in 2004-05 were used. Results showed that the impact of lignite mine waters on total heavy metals in river sediments was low in the case of the Noteć and Pichna rivers. In Grójecki Channel at the site situated $1 \mathrm{~km}$ below the mine waters discharge the total heavy metal concentration in the bottom substrate was significantly higher than above the mine waters discharge outlet. An opposite trend was observed in the Widawka River sediments ( $715 \mathrm{mg}$ of heavy metals $\mathrm{kg}^{-1}$ of dry matter), where the total heavy metal concentration in the substrate $1 \mathrm{~km}$ below the mine waters discharge outlet decreased by approx. $44 \%$. This was related to low concentrations of heavy metals in the Bełchatów mine waters, amounting to $0.033 \mathrm{mg} \cdot \mathrm{L}^{-1}$.
\end{abstract}

Keywords: mine waters, heavy metals, brown coal

\section{Introduction}

Brown coal is an important natural resource used in Poland and other countries, e.g. Germany, Russia, Turkey, Greece, etc., for power generation. It is an important fossil fuel and is found in several regions of Poland, including the Wielkopolskie, Łódzkie, and Dolnośląskie provinces and there is a potential for brown coal mining in Lubuskie province, [1]. New open-pit mines are going to be opened in Wielkopolska Province, i.e. the Mąkoszyn-Grochowiska mine and possibly in Czempiń, Krzywiń, and Gostyń. Currently, about $35 \%$ of energy production in Poland comes from brown coal and new open-pit mines because of the low price of such a energy production in comparison to

\footnotetext{
*e-mail: erstan@up.poznan.pl
}

other sources. [2]. Due the technology of excavation, openpit mines cause several changes in the environment, such as shifts in landscape structure and changes of local hydrology and hydrogeology, while they also affect air quality, create a cone of depression by drainage, and thus press on surface waters. In the regions mentioned above there exists a potential risk for river water quality related to the presence of heavy metals in mine waters. Two types of lignite mine waters are present, i.e. mine waters from deep-seated drainage with mostly good quality, which may be discharged to rivers without treatment, and surface drainage, which requires treatment in settling reservoirs and sometimes application of chemicals, such as PIX, to increase the rate of coagulation and sedimentation $[3,4]$.

Studies on heavy metals covering many environmental issues and interactions have a long history in Poland and 
other countries. This is due to their importance for the functioning of different ecosystems and for environmental health. Toxic effects of cadmium, lead, chromium, and other heavy metals have been intensively studied also due to their importance for water quality and human health [521]. Other parameters, such as conductivity and $\mathrm{pH}$ of water and sediments, also play an important role in the evaluation of mine water impact on river ecosystems and have been utilized during studies. Former surveys showed that changes in water quality parameters caused by lignite mine waters can affect biological diversity of aquatic plants and to some extent values of macrophyte indices [4].

\section{Study Area}

The impact of mine waters from four brown coal open pit-mines located in central Poland on river water quality was studied. The open pit mines in Lubstów, Tomisławice, and Drzewce are situated in the Konin Coal Mine (Wielkopolskie Province) and the fourth mine was in the Bełchatów field of the Bełchatów coal mine (Łódzkie Province). Mine water discharge from Lubstów pit was stopped in April 2009, while the other open-pit mines were active during the study period. In the Tomisławice mine extraction was started in September 2011. In the case of the Lubstów and Drzewce mines the examined waters came from deep-seated drainage, in Bełchatów they were mixed waters leaving the settling reservoir and in Tomisławice they were waters from surface drainage leaving the settling reservoir.

The Lubstów mine was situated in the rural landscape with predominant mineral soils, and mine waters from deep seated drainage (clean waters) were discharged without treatment to the Noteć River [22]. Organic soils susceptible to degradation and varying in their physico-chemical characteristics were found around the new open-cast mine in Tomisławice [23]. Mine waters from Drzewce open-pit mine were discharged to the Grójecki Channel situated in an area dominated by hydrogenic soils susceptible to subsurface

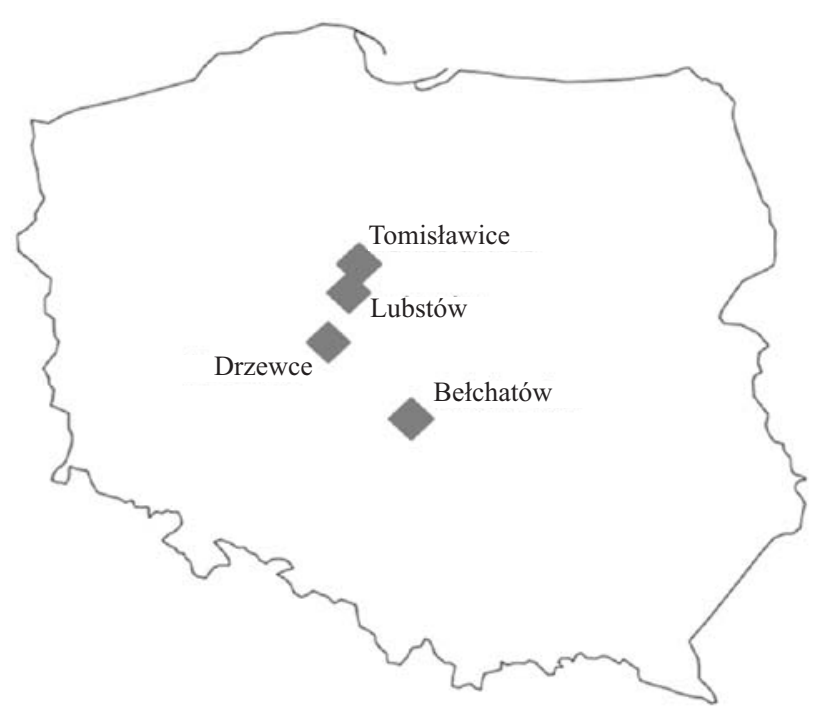

Fig. 1. Location of studied brown coal mines in Poland. drainage [24]. All the mines mentioned above were located in an area with low precipitation, which induced droughts in lowland areas and affected agricultural activities [25, 26].

In the Bełchatów open-pit mine the substrate above the coal layer was dominated by sands and the salt dome in Dębina. Precipitation is higher than in the previous locations, but soils are susceptible to degradation caused by mine drainage [27-29].

\section{Methods}

In 2011-13 the analyses of heavy metals, iron, and manganese concentrations in waters and sediments of rivers affected by brown coal mine waters were undertaken in the Pichna (Tomisławice open pit-mine, May-June 2011, July 2013), Widawka (Bełchatów open-pit mine, May and June 2012), and Grójecki Channel (Drzewce open-pit mine, July and August 2013). According to observations started in 2003, the Pichna River is a periodic river with no water flow in the summer period and for this reason water quality parameters were studied in May and June. In the case of the Noteć River (Lubstów open-pit mine), results of water sample analyses from 2004-05 were used and sediment samples were collected in July 2012, three years after mine waters discharge had been stopped. Other important parameters of water and sediment quality were measured in 2011-13 during the warm period and mean values are presented in this paper, except for the median for $\mathrm{pH}$ reaction. River water and sediment samples were collected in the river current at three sites: $\mathrm{A}-50$ metres above the mine waters discharge outlet, $\mathrm{B}-100$ metres below it, and $\mathrm{C}-$ 1000 metres below the discharge. The last site was in the location of complete mixing of river and mine waters [30]. Samples of the bottom substrate collected for analyses were bulk samples from three subsamples from the $5 \mathrm{~cm}$ deep layer.

Analytical procedures for sediment samples:

- Cadmium, chrome, copper, lead, nickel, zinc, iron, manganese - determined from aqua regia extracts obtained after $16 \mathrm{~h}$ extraction, metals were analyzed with an atomic absorption spectrometer in the flame mode, at the detection limits of $0.1 \mathrm{mg} \cdot \mathrm{kg}^{-1}$,

- $\mathrm{pH}_{\mathrm{KCl}}$ and conductivity - electrometrically. Analytical procedures for water samples:

- Cadmium, chrome, copper, lead, nickel, zinc, iron, manganese - samples were concentrated using ionexchangers, metals were analyzed with an atomic absorption spectrometer in the flame mode, at the detection limits of $0.001 \mathrm{mg} \cdot \mathrm{L}^{-1}$,

- $\mathrm{pH}$ reaction, conductivity - electrometrically in the field.

\section{Results and Discussion}

In the upper course of the Notec River watershed the water quality in the river depends on many factors, such as the presence of lakes, agricultural activities, brown coal mining and low precipitation $[4,26,31-33]$. The impact of mine waters (deep-seated drainage) from the open-pit mine 
Table 1. Median of $\mathrm{pH}$ reaction, mean values of conductivity and its standard deviation in mine waters from studied open-pit mines.

\begin{tabular}{|c|c|c|c|}
\hline $\begin{array}{c}\text { Open pit } \\
\text { mine }\end{array}$ & $\begin{array}{c}\text { Mine water quality } \\
\text { parameter }\end{array}$ & Mean & $\begin{array}{c}\text { Standard } \\
\text { deviation }\end{array}$ \\
\hline \multirow{2}{*}{ Lubstów } & $\mathrm{pH}$ & $7.46^{*}$ & 0.16 \\
\cline { 2 - 4 } & Conductivity, $\left(\mathrm{mS} \cdot \mathrm{cm}^{-1}\right)$ & 0.629 & 0.169 \\
\hline \multirow{2}{*}{ Tomisławice } & $\mathrm{pH}$ & 7.73 & 0.02 \\
\cline { 2 - 4 } & Conductivity, $\left(\mathrm{mS} \cdot \mathrm{cm}^{-1}\right)$ & 0.422 & 0.036 \\
\hline \multirow{2}{*}{ Bełchatów } & $\mathrm{pH}$ & 7.67 & 0.07 \\
\cline { 2 - 4 } & Conductivity, $\left(\mathrm{mS} \cdot \mathrm{cm}^{-1}\right)$ & 0.903 & 0.060 \\
\hline \multirow{2}{*}{ Drzewce } & $\mathrm{pH}$ & 7.70 & 0.32 \\
\cline { 2 - 4 } & Conductivity, $\left(\mathrm{mS} \cdot \mathrm{cm}^{-1}\right)$ & 0.457 & 0.053 \\
\hline
\end{tabular}

*median for $\mathrm{pH}$ reaction

Table 2. Sum of heavy metals (cadmium, chrome, copper, lead, nickel, zinc) for studied river waters in three sites (A - 50 metres above mine waters discharge, $\mathrm{B}-100$ metres below and $\mathrm{C}-1000$ metres below discharge) and the sum of heavy metals in mine waters.

\begin{tabular}{|l|c|c|c|c|}
\hline & \multicolumn{3}{|c|}{$\begin{array}{c}\text { Sum of heavy metals in river } \\
\text { waters }\end{array}$} & $\begin{array}{c}\text { Sum of heavy } \\
\text { metals in } \\
\text { mine waters }\end{array}$ \\
\hline $\begin{array}{c}\text { River/open-pit } \\
\text { mine }\end{array}$ & $\mathrm{A}$ & $\mathrm{B}$ & $\mathrm{C}$ & $\mathrm{m} \cdot \mathrm{L}^{-1}$ \\
\hline $\begin{array}{l}\text { Noteć R./ } \\
\text { Lubstów }\end{array}$ & $-*$ & - & - & $0.060 * *$ \\
\hline $\begin{array}{l}\text { Pichna R./ } \\
\text { Tomisławice }\end{array}$ & 0.057 & 0.043 & 0.030 & 0.035 \\
\hline $\begin{array}{l}\text { Widawka R./ } \\
\text { Bełchatów }\end{array}$ & 0.063 & 0.060 & 0.066 & 0.033 \\
\hline $\begin{array}{l}\text { Grójecki } \\
\text { Channel/ } \\
\text { Drzewce }\end{array}$ & 0.106 & 0.098 & 0.084 & 0.079 \\
\hline
\end{tabular}

*in 2004-09 the total concentrations of metals in river waters were not analyzed,

**data from Konin Coal Mine (personal communication) for years 2004-09

Lubstów (Table 1), which was closed in 2009, was not significant for the Noteć River. In 2004-05 all studied water quality parameters of the Notec were in the first category of water quality [34], except conductivity in A, where mean value $1.027 \mathrm{mS} \cdot \mathrm{cm}^{-1}$ was in second category. Below the mine waters discharge it fall to $0.873-0.911 \mathrm{mS} \cdot \mathrm{cm}^{-1}$ (sites $\mathrm{B}$ and $\mathrm{C}$ respectively) due to the lower mean conductivity of mine waters equal to $0.682 \mathrm{mS} \cdot \mathrm{cm}^{-1}$ (Table 1). In the years 2004-05 the amount of heavy metal in mine waters was equal to $0.060 \mathrm{mg} \cdot \mathrm{L}^{-1}$ (Table 2, Konin Coal Mine - personal communication). Three years after closure of the Lubstów mine the total heavy metal concentration in the bottom substrate was similar above and below the mine waters discharge and was the lowest $\left(25.9 \mathrm{mg} \cdot \mathrm{kg}^{-1}\right)$ among the surveyed rivers (Table 3 ). The $\mathrm{pH}$ reaction changed from 7.50 in site A to 4.86 in site $\mathrm{C}$. Low $\mathrm{pH}$ of sediments in site $\mathrm{C}$ was also observed earlier ( $\mathrm{pH} 4.58$, own analyses) and this could be related to eutrophic conditions in the Noteć River, where during summer a low level of oxygen is present [33].

In the years 2011 and 2013 most of the water quality parameters presented in this paper (including metals) were acceptable in the Pichna River. At site $\mathrm{C}$ increased contents of manganese $\left(0.18 \mathrm{mg} \mathrm{Mn} \cdot \mathrm{L}^{-1}\right)$ and iron $\left(0.87 \mathrm{mg} \mathrm{Fe} \cdot \mathrm{L}^{-1}\right)$ were observed in comparison to site A $\left(0.15 \mathrm{mg} \mathrm{Mn} \cdot \mathrm{L}^{-1}\right.$, $\left.0.47 \mathrm{mg} \mathrm{Fe} \cdot \mathrm{L}^{-1}\right)$. Total heavy metal contents in sediments were found to be higher at site $\mathrm{C}\left(31.1 \mathrm{mg} \cdot \mathrm{kg}^{-1}\right)$ than at site B (20.0 $\left.\mathrm{mg} \cdot \mathrm{kg}^{-1}\right)$, and slightly lower than at site A (38.8 $\mathrm{mg} \cdot \mathrm{kg}^{-1}$ ) situated above the mine waters discharge outlet (Table 3), which was typical of the studied rivers. The greatest level of iron in sediments was observed at site A and was equal to $5,020 \mathrm{mg} \mathrm{Fe} \cdot \mathrm{L}^{-1}$. The $\mathrm{pH}$ reaction changed from 7.60 at site A to 6.84 at site C. Conductivity of river sediments $1 \mathrm{~km}$ below the mine waters discharge was 1.443 $\mathrm{mS} \cdot \mathrm{cm}^{-1}$ (class 2) and was the highest observed during surveys.

In 2012 total heavy metal content in mine waters discharged to the Widawka was the lowest observed and reached $0.033 \mathrm{mg} \cdot \mathrm{L}^{-1}$, causing a decrease of this parameter at river site $\mathrm{B}$, but there was no impact after complete mixing of river and mine waters (Table 2 ). At site $\mathrm{C}$ a negligible increase was observed for manganese $\left(0.46 \mathrm{mg} \mathrm{Mn} \cdot \mathrm{L}^{-1}\right)$ and chrome $\left(0.007 \mathrm{mg} \mathrm{Cr} \cdot \mathrm{L}^{-1}\right)$ concentrations in comparison to site A $\left(0.38 \mathrm{mg} \mathrm{Mn} \cdot \mathrm{L}^{-1}, 0.004 \mathrm{mg} \mathrm{Cr} \cdot \mathrm{L}^{-1}\right)$. In terms of total heavy metal contents in the Widawka sediments the situation improved significantly from $715 \mathrm{mg} \cdot \mathrm{kg}^{-1}$ at site A to less than $400 \mathrm{mg} \cdot \mathrm{kg}^{-1}$ at sites B and C (Table 3). Such metals as manganese and iron were strongly represented in sediments above Bełchatów mine and reached 3,320 $\mathrm{mg} \mathrm{Mn} \cdot \mathrm{kg}^{-1}$ and 42,400 $\mathrm{mg} \mathrm{Fe} \cdot \mathrm{kg}^{-1}$ (site A), and were lower at the site situated $1 \mathrm{~km}$ below the mine waters discharge (C), falling to $1,970 \mathrm{mg} \mathrm{Mn} \cdot \mathrm{kg}^{-1}$ and $34,400 \mathrm{mg}$ $\mathrm{Fe} \cdot \mathrm{kg}^{-1}$, respectively. The $\mathrm{pH}$ values of river sediments were similar at site $\mathrm{A}(\mathrm{pH} 7.32)$ and sites below the mine waters discharge $(\mathrm{B}, \mathrm{pH} 7.48, \mathrm{C}, \mathrm{pH}$ 7.34). Conductivity of river sediments $1 \mathrm{~km}$ below the discharge was equal to 1.382 $\mathrm{mS} \cdot \mathrm{cm}^{-1}$, while at site A it was equal to $1.135 \mathrm{mS} \cdot \mathrm{cm}^{-1}$.

In 2013 the $\mathrm{pH}$ reaction of Drzewce mine waters were characterized by a wide range of values in comparison to other mines (Table 1). The total heavy metal contents in mine waters discharged to the Grójecki Channel were the highest observed and was equal to $0.079 \mathrm{mg} \cdot \mathrm{L}^{-1}$, but it caused a reduction of this parameter at river sites $\mathrm{B}$ and $\mathrm{C}$ due to high concentrations of heavy metals at the site above the mine waters discharge (Table 2). At site $\mathrm{C}$ a negligible increase of manganese $\left(0.08 \mathrm{mg} \mathrm{Mn} \cdot \mathrm{L}^{-1}\right)$, iron $(1.20 \mathrm{mg}$ $\left.\mathrm{Fe} \cdot \mathrm{L}^{-1}\right)$, and chrome $\left(0.037 \mathrm{mg} \mathrm{Cr} \cdot \mathrm{L}^{-1}\right)$ concentrations was observed in comparison to site A $\left(0.04 \mathrm{mg} \mathrm{Mn} \cdot \mathrm{L}^{-1}, 0.36 \mathrm{mg}\right.$ $\left.\mathrm{Fe} \cdot \mathrm{L}^{-1}, 0.032 \mathrm{mg} \mathrm{Cr} \cdot \mathrm{L}^{-1}\right)$. The total heavy metal content in the bottom substrate of Grójecki Channel was the highest at site $\mathrm{C}$ and equal to $61.1 \mathrm{mg} \cdot \mathrm{kg}^{-1}$ (Table 3 ). A very high concentration of iron was observed in the riverbed substrate from site $\mathrm{C}$ equal to $57,300 \mathrm{mg} \mathrm{Fe} \cdot \mathrm{kg}^{-1}$, which was over 7 
Table 3. River bottom substrate and sum of heavy metals (cadmium, chrome, copper, lead, nickel, zinc) in river sediments (A - 50 metres above mine waters discharge, B - 100 metres below and C - 1000 metres below discharge, min - mineral substrate, min/org mineral/organic substrate).

\begin{tabular}{|c|c|c|c|c|}
\hline \multirow{2}{*}{ River } & \multirow{2}{*}{ Parameter } & \multicolumn{3}{|c|}{ Site } \\
\hline & & A & $\mathrm{B}$ & $\mathrm{C}$ \\
\hline \multirow{2}{*}{ Noteć R. } & Substrate & $\min$ & $\min$ & $\min$ \\
\hline & Heavy metals (mg.kg ${ }^{-1}$ d.m.) & 22.8 & 13.8 & 25.9 \\
\hline \multirow{2}{*}{ Pichna R. } & Substrate & $\min$ & $\min$ & $\mathrm{min} /$ org \\
\hline & Heavy metals (mg. $\mathrm{kg}^{-1}$ d.m.) & 38.8 & 20.0 & 31.1 \\
\hline \multirow{2}{*}{ Widawka R. } & Substrate & $\mathrm{min} /$ org & $\mathrm{min} / \mathrm{org}$ & $\mathrm{min} /$ org \\
\hline & Heavy metals (mg.kg-1 d.m.) & 715 & 393 & 398 \\
\hline \multirow{2}{*}{ Grójecki Channel } & Substrate & $\min /$ org & $\min$ & $\mathrm{min} /$ org \\
\hline & Heavy metals (mg. $\mathrm{kg}^{-1}$ d.m.) & 39.2 & 25.1 & 61.1 \\
\hline
\end{tabular}

times higher than at site A. It was probably the effect of sediment characteristics at site $\mathrm{B}$, where the mineral permeate substrate was found, accumulating non-significant amounts of metals, whilst at site $\mathrm{C}$ the mineral-organic more cumulative substrate was observed. Additionally, at site B the river and mine waters were not completely mixed yet. The $\mathrm{pH}$ reaction of river sediments was similar at site $\mathrm{A}(\mathrm{pH}$ 7.23) and in site $\mathrm{C}(\mathrm{pH} 7.10)$. Conductivity of river sediments $1 \mathrm{~km}$ below the discharge outlet was equal to 0.849 $\mathrm{mS} \cdot \mathrm{cm}^{-1}$ and it was higher than at site $\mathrm{A}\left(0.527 \mathrm{mS} \cdot \mathrm{cm}^{-1}\right)$.

In the studied rivers sediment conductivity was always higher at sites $\mathrm{C}$ than above the mine waters discharge outlet (sites A), regardless of the type of mine waters and duration of mine waters impact on the river ecosystem. To some extent it was also observed in the case of several metals such as chrome, copper, cadmium, lead, and total heavy metals (Fig. 2). In comparison to other data for rivers in Poland the concentrations of heavy metals in sediments of the studied rivers were low except for manganese in the Widawka River, and manganese and iron in Grójecki Channel (Table 4).

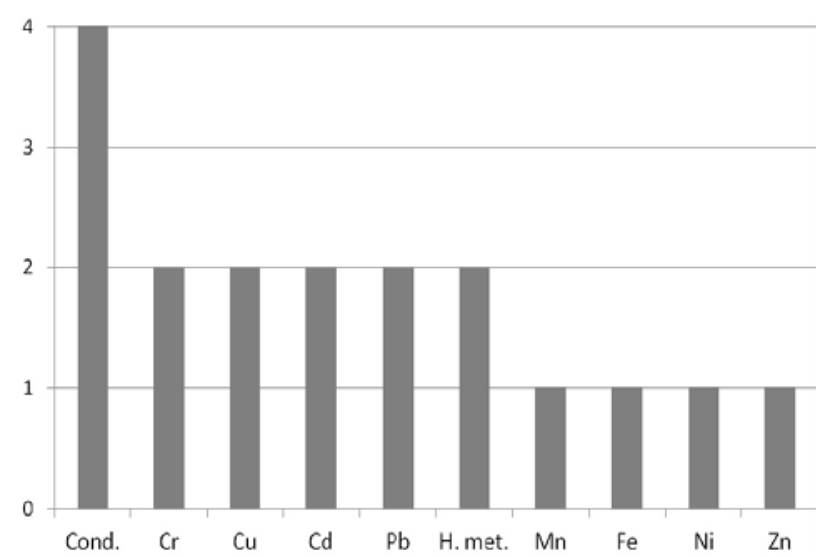

Fig. 2. Number of open-pit mines where select sediment quality parameters were higher in sites located $1 \mathrm{~km}$ below than in sites above mine waters discharge (Cond. - conductivity, H. met. - sum of heavy metals).
A decrease of total heavy metal concentrations at sites $\mathrm{B}$ and its increase at sites $\mathrm{C}$ (Table 3 ) were probably related to the higher river discharge caused by mine waters, thus washing out a portion of sediments from sites B to C. The rate of mine waters discharge in the Pichna River was even $100 \%$ during the summer period, in the Widawka the average was equal to $15 \%$ [29], in the Noteć it was $21 \%$ [42], and $10-20 \%$ in Grójecki Channel [authors' observations]. The change in the substrate structure was most evident in the case of Grójecki Channel and the Pichna River, where site $\mathrm{B}$ was mineral and site $\mathrm{C}$ was partially mineral and organic (Table 3). A similar phenomenon was observed in the middle course of the Odra River, where small grain size particles characterized by high metal contents were washed out from the central parts of the riverbed and deposited along the riverbank, causing an increase in heavy metals concentrations [43].

\section{Conclusions}

1. The sum of heavy metals concentrations in brown coal mine waters was lower than in rivers that cause a decrease of this parameter below the mine waters discharge.

2. Higher concentrations of particular metals at the river sites below the mine waters discharge were sporadically observed for chrome (Bełchatów and Drzewce openpit mines), zinc (Bełchatów), manganese (Tomisławice, Bełchatów, Drzewce) and iron (Drzewce).

3. Brown coal mine waters, despite the duration of impact, caused a decrease of the total heavy metal concentrations in river sediments 100 meters below the mine waters discharge and a subsequent increase after complete mixing with river waters at sites situated $1 \mathrm{~km}$ below the discharge. In the case of the Lubstów and Drzewce open-pit mines the concentrations at sites $1 \mathrm{~km}$ below the discharge were greater than the values observed at the sites located above the mine waters discharge. 
Table 4. Ranges of heavy metals concentrations, manganese, iron, conductivity and $\mathrm{pH}$ reaction in sediments of Noteć, Pichna, Widawka and Grójecki Channel rivers collectively ( $\mathrm{A}-50$ metres above mine waters discharge, $\mathrm{B}-100$ metres below and $\mathrm{C}-1000$ metres below discharge) and comparison to data from Poland [18, 35-41].

\begin{tabular}{|c|c|c|c|c|c|}
\hline \multirow{2}{*}{ Parameter } & \multirow[t]{2}{*}{ Unit } & \multicolumn{3}{|c|}{ Site } & \multirow{2}{*}{ Poland } \\
\hline & & A & B & $\mathrm{C}$ & \\
\hline $\mathrm{Cr}$ & \multirow{8}{*}{$\begin{array}{l}\mathrm{mg} \cdot \mathrm{kg}^{-1} \text { of } \\
\text { dry matter }\end{array}$} & $1.4-7.0$ & $0.9-4.4$ & $1.9-6.5$ & $1-1090$ \\
\hline $\mathrm{Ni}$ & & $3.1-152$ & $1.1-83.5$ & $1.9-72.9$ & $1-667$ \\
\hline $\mathrm{Cu}$ & & $3.3-30.0$ & $1.5-28.1$ & $1.6-22.3$ & $1-3700$ \\
\hline $\mathrm{Zn}$ & & $13.4-507$ & $9.1-255$ & $8.0-282$ & 4-12000 \\
\hline $\mathrm{Cd}$ & & $<0.1-0.9$ & $<0.1-0.4$ & $<0.1-0.7$ & $0.25-1160$ \\
\hline $\mathrm{Pb}$ & & $1.7-18.4$ & $<0.1-21.3$ & $5.3-14.1$ & $<5-4519$ \\
\hline $\mathrm{Fe}$ & & $3840-42400$ & $1070-29400$ & $3630-57300$ & $1000-73810$ \\
\hline $\mathrm{Mn}$ & & $90-3320$ & $7-2540$ & $13-1970$ & $187.7-2581$ \\
\hline Conductivity & $\mathrm{mS} \cdot \mathrm{cm}^{-1}$ & $0.083-1.135$ & $0.069-0.998$ & $0.400-1.443$ & $0.225-1.030$ \\
\hline $\mathrm{pH}$ reaction & - & $7.23-7.60$ & $7.06-7.93$ & $4.86-7.34$ & $6.90-7.98$ \\
\hline
\end{tabular}

4. Metal contents in river sediments were low and they were significantly lower than the maximum values found in Poland, except for iron and manganese.

5. In all studied rivers mine waters caused sediment conductivity at sites $1 \mathrm{~km}$ below the discharge to be higher than in upper sites, which indicates the impact of mine waters on sediment salinity.

6. Total concentrations of heavy metals were decreasing in sites $\mathrm{B}$ and then increasing in sites $\mathrm{C}$ due to the mine waters impact on riverbed material.

\section{Acknowledgements}

Studies were financed by the National Science Centre in Poland (NCN) according to decision DEC-2011/01/B/ ST10/00513 (2011-13) and partially under project KBN 2 P06S 01927 of the State Committee for Scientific Research (2004-06).

\section{References}

1. TAJDUŚ A., CZAJA P., KASZTELEWICZ Z. Actual state and prognosis of development of brown coal branch in first half of XXI century in Poland. Górnictwo i Geologia 5, (3), 138, 2010 [In Polish].

2. KASZTELEWICZ Z. Lignite deposits in Poland and perspectives of their utilization Polityka energetyczna, 11, (1), 181, 2008 [In Polish].

3. SAWICKI J. Hydrogeological conditions and mining operation brown coal deposits Złoczew. Prace Naukowe Instytutu Górnictwa Politechniki Wrocławskiej, 123, (34), 127, 2010 [In Polish].

4. STANISZEWSKI R., JUSIK S. Impact of mine waters discharge from open-pit lignite mine on river water quality. Rocznik Ochrona Środowiska 15, (3), 2652, 2013 [In Polish].
5. ADAMIEC E., HELIOS-RYBICKA E. Distribution of Pollutants in the Odra River System Part V. Assessment of total and mobile heavy metals content in the suspendent matter and sediments of the Odra River system and recommendations for river chemical monitoring. Pol. J. Environ. Stud. 11, (6), 675, 2002.

6. DRZEWIECKA K., BOROWIAK K., MLECZEK M., ZAWADA I., GOLIŃSKI P. Bioaccumulation of zinc and copper by Phragmites australis (Cav.) Trin Ex Steudel and Typha angustifolia (L.) growing in natural water ecosystems. Fresen Environ Bull 20, (2), 325, 2011.

7. GŁOSIŃSKA G., SOBCZYŃSKI T., BOSZKE L., BIERŁA K., SIEPAK J. Fractionation of Some Heavy Metals in Bottom Sediments from the Middle Odra River (Germany/Poland), Pol. J. Environ. Stud. 14, (3), 305, 2005.

8. GRABIŃSKA B., KOC J., SZYMCZYK S. Fluctuations in Concentration of Zinc in River Waters Depending on Environmental Conditions and Type of Use of a River Basin: a Case Study of the Narew River and Some of Its Tributaries, Pol. J. Environ. Stud. 15, (2a), 78, 2006.

9. OCIEPA-KUBICKA A., OCIEPA E. Toxic effects of heavy metals on plants, animals and humans. Inżynieria i Ochrona Środowiska 15, (2), 169, 2012 [In Polish].

10. OLADE M.A. Dispersion of cadmium, lead and zinc in soils and sediments of humid tropical ecosystem in Nigeria. In: T. C. Hutchinson and K. M. Meema (Eds), Lead, mercury, cadmium and arsenic in the environment, SCOPE, John Wiley \& Sons Ltd, pp. 303-313, 1987.

11. SOBCZYŃSKI T., KAŹMIERCZAK J., ZIOŁA A. The effect of a depression sink on a accumulation of heavy metals in bottom sediments of old riverbeds in the range of its influence. Pol. J. Environ. Stud. 13, 101, 2004.

12. SOJKA M., SIEPAK M., GNOJSKA E. Assessment of heavy metal concentration in bottom sediments of Stare Miasto pre-dam reservoir on the Powa River. Rocznik Ochrona Środowiska 15, (3), 1916, 2013 [In Polish].

13. SOYLAK M., DIVRIKLI U., SAROCOGLU S., ELCI L. Monitoring Trace Metal Levels in Yozgat-Turkey: Copper, Iron, Nickel, Cobalt, Lead, Cadmium, Manganese and 
Chromium Levels in Stream Sediments. Pol. J. Environ. Stud. 11, (1), 47, 2002.

14. STANISZEWSKI R. Lead contamination of vegetables. Przyroda i człowiek. Akademickie Centrum Edukacji Ekologicznej. Opole, pp. 153-156, 1993 [In Polish].

15. STANISZEWSKI R. Metals in waters, soils and plants of Brodnicki Landscape Park. Przyroda i człowiek. Opolskie Centrum Edukacji Ekologicznej. Opole, pp. 153-155, 1995 [In Polish].

16. SZYCZEWSKI P., SIEPAK J., NIEDZIELSKI P., SOBCZYŃSKI T. Research on heavy metals in Poland, Pol. J. Environ. Stud. 18, (5), 755, 2009.

17. SZYSZLAK-BARGŁOWICZ J., SŁOWIK T., ZAJĄC G., PIEKARSKI W. The content of heavy metals in the drainage ditches by communication routes. Rocznik Ochrona Środowiska 15, 2309, 2013 [In Polish].

18. WARDAS M., ALEKSANDER-KWATERCZAK U., JUSIK S., HRYC B., ZGOŁA T., SZTUKA M., KACZMARSKA M., MAZUREK M. An attempt to assess the impact of anthropopressure on the ecological state of urbanised watercourses of Kraków conurbation and the difficulties encountered. J. Elem. 15, (4), 725, 2010.

19. ZERBE J., SOBCZYŃSKI T., ELBANOWSKA H., SIEPAK J. Speciations of heavy metals in bottom sediments of lakes. Pol. J. Environ. Stud. 8, (5), 331, 1999.

20. ZIOŁA-FRANKOWSKA A., FRANKOWSKI M., SZCZUCIŃSKI W., SIEPAK J. Analysis of labile aluminium form in grain size fractions of tsunami deposit in Thailand. Pol. J. Environ. Stud. 18, (1), 77, 2009.

21. ZIOŁA A., SZYMAŃSKI M., SOBCZYŃSKI T. Heavy metals in water, bottom sediments and plants collected from Jarosławieckie Lake from area of Wielkopolski National Park. Ecology and Technology 13, (6), 223, 2005 [In Polish].

22. DOMSKA D., RACZKOWSKI M. Effect of strip mine activity on changes of some physicochemical properties of soil Acta Agrophysica 12, (1), 73, 2008 [In Polish].

23. JAKUBUS M., GAJEWSKI P., KACZMAREK Z. Physicochemical and chemical properties of surface layers of selected soils located in the vicinity of the planned Tomisławice open-cast lignite mine. Rocznik Ochrona Środowiska, 15, 2232, 2013 [In Polish].

24. OWCZARZAK W., MOCEK A., GAJEWSKI P. Water properties of organic soils of the Grójec Valley situated in the neighbourhood of Drzewce opencast brown coal mine. Acta Agrophysica 1, (4), 711, 2003 [In Polish].

25. KUNDZEWICZ Z.W., ZALEWSKI M., KĘDZIORA A., PIERZGALSKI E. Water-related threats. Nauka 4, 87, 2010 [In Polish].

26. SZAFRAŃSKI CZ., STACHOWSKI P., KOZACZYK P. Actual condition and forecast of improvement of water management is soil of post mining grounds. Rocznik Ochrona Środowiska 13, 485, 2011 [In Polish].

27. MIATKOWSKI Z., TURBIAK S., KOWALIK W., SOŁTYSIK A., LEWIŃSKI J. Applicability of landsat TM satellite images to identification of intensively drained hydrogenic sites in the region of the brown coal mine Bełchatów. Water, Environment, Rural Areas. Treatises and Monographs, IMUZ Falenty, 16, 80, 2006 [In Polish].

28. MOTYKA J., CZOP M., JOŃCZYK W., STACHOWICZ Z., JOŃCZYK I., MARTYNIAK R. The impact of deep exploitation of brown coal on changes of aquatic environment near Bełchatów coal mine. Górnictwo i Geoinżynieria 31, (2), 477, 2007 [In Polish].

29. WACHOWIAK G., GALINIAK G., JOŃCZYK W., MARTYNIAK R. Estimation of run-off changes in Widawka River watershed in the hydrological year 2010 under pressure of mine-energetic investment in Bełchatów area. Górnictwo i Geoinżynieria 35, (3), 381, 2011 [In Polish].

30. SKOWYSZ A. About using an empirical formulas for estimating the length of complete mixing waste waters discharger into rivers and the channels. Scientific review Engineering and Environmental Sciences, 53, 237, 2011 [In Polish].

31. STANISZEWSKI R., SZOSZKIEWICZ J. Threats of freshwaters in Southern Kujawy on an example of selected lakes and watercourses. Kształtowanie środowiska - zagrożenia i monitoring. Zeszyty Problemowe Postępów Nauk Rolniczych 505, 407, 2005 [In Polish].

32. STANISZEWSKI R., SZOSZKIEWICZ J. Changes in the quality of water in Brdowskie Lake in the years in 19972006. J. Elem., 15, (4), 705, 2010.

33. STANISZEWSKI R., SZOSZKIEWICZ J. Freshwater quality of Kujawskie Lakeland and possibilities of its use. Pol. J. Environ. Stud. 11, 51, 2002.

34. DECREE OF MINISTRY OF ENVIRONMENT according to the way of classification of integrated parts of freshwaters and environmental quality normative for priority substances. J. Law. No. 257 Item. 1545, pp. 15059-15097, 2011 [In Polish].

35. BARBUSIŃSKI K., NOCOŃ W. Heavy metal compounds in the bottom sediments of the River Kłodnica (Upper Silesia). Ochrona Środowiska 33, (1), 13, 2011 [In Polish].

36. BOJAKOWSKA I., GLIWICZ T., MAŁECKA K. Results of geochemical survey of aquatic sediments in Poland in the years 2003-2005. Biblioteka Monitoringu Środowiska, IOŚ Warszawa, pp. 116, 2006 [In Polish].

37. HELIOS-RYBICKA E., ADAMIEC E., ALEKSANDERKWATERCZAK U. Distribution of trace metals in the Odra River system: Water-suspended matter-sediments. Limnologica 35, 185, 2005.

38. KORABIEWSKI B. The trace of human activity in water sediments in the upper Kwisa catchments. In: A. Szponar, S. Horska-Schwarz (Eds), The spatial-functional structure of landscape, Wrocław, 249-256, 2005 [In Polish].

39. MIGASZEWSKI Z.M., GAŁUSZKA A. Chemical composition of waters and sediments of selected rivers of Wigierski National Park and Suwałki area, and sediments of Wigry Lake. NFOŚiGW, Kielce, pp. 8, 2003 [In Polish].

40. PAJAZK B. (Ed), Report of state of the environment in Małopolskie voivodship in the year 2009. WIOŚ Kraków, pp. 78, 2010 [In Polish].

41. SKORBIŁOWICZ E. Evaluation of environmental quality in selected rivers of Siemiatycze District. Woda-ŚrodowiskoObszary wiejskie, 4, (11), 429, 2004 [In Polish].

42. WACHOWIAK G. The upper Noteć River recharge from mine water of open pit mine Lubstów of the Konin lignite mine. Górnictwo Odkrywkowe, 1, 54, 2010 [In Polish].

43. FRANKOWSKI M., SOBCZYŃSKI T., ZIOŁA A. The effect of grain size structure on the content of heavy metals in alluvial sediments of the Odra River. Pol. J. Environ. Stud., 14, 81, 2005. 